\title{
Hydrologic Evaluation of the Jungo Area, Southern Desert Valley, Nevada
}

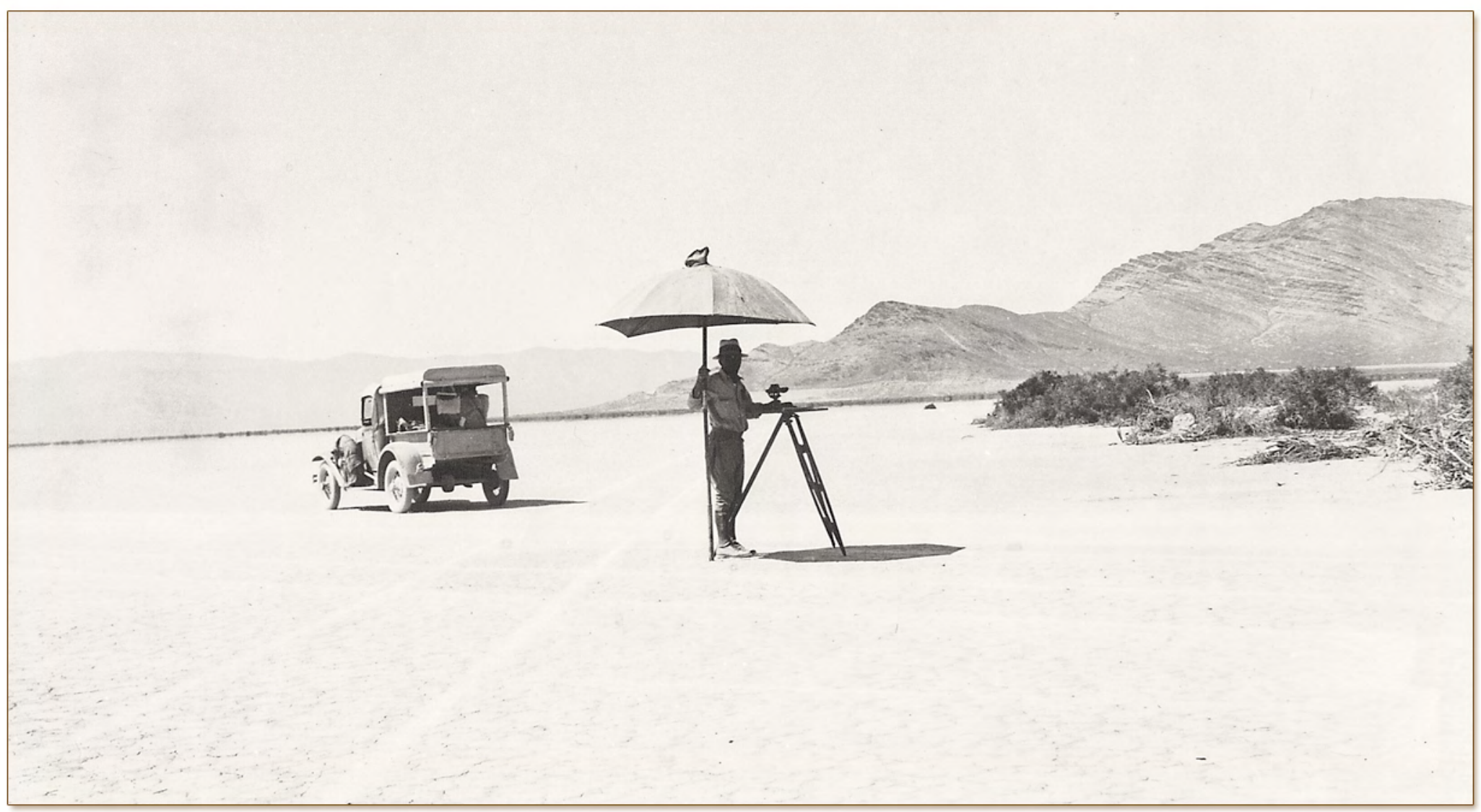

Open-File Report 2010-1009 
Cover: Mapping the north half of the Lovelock $1^{\circ}$ quadrangle in the desert area near Jungo, Nevada, August 1931. Photograph from U.S. Geological Survey historical photograph collection. 


\section{Hydrologic Evaluation of the Jungo Area, Southern Desert Valley, Nevada}

By Thomas J. Lopes

Open-File Report 2010-1009

U.S. Department of the Interior U.S. Geological Survey 


\title{
U.S. Department of the Interior \\ KEN SALAZAR, Secretary
}

\section{U.S. Geological Survey \\ Marcia K. McNutt, Director}

U.S. Geological Survey, Reston, Virginia: 2010

\begin{abstract}
For more information on the USGS-the Federal source for science about the Earth, its natural and living resources, natural hazards, and the environment, visit $h t t p: / / w w w . u s g s . g o v$ or call 1-888-ASK-USGS.

For an overview of USGS information products, including maps, imagery, and publications, visit http://www.usgs.gov/pubprod
\end{abstract}

To order this and other USGS information products, visit http://store.usgs.gov

Suggested citation:

Lopes, T.J., 2010, Hydrologic evaluation of the Jungo area, southern Desert Valley, Nevada: U.S. Geological Survey Open-File Report 2010-1009,10 p.

Any use of trade, product, or firm names is for descriptive purposes only and does not imply endorsement by the U.S. Government.

Although this report is in the public domain, permission must be secured from the individual copyright owners to reproduce any copyrighted material contained within this report. 


\section{Contents}

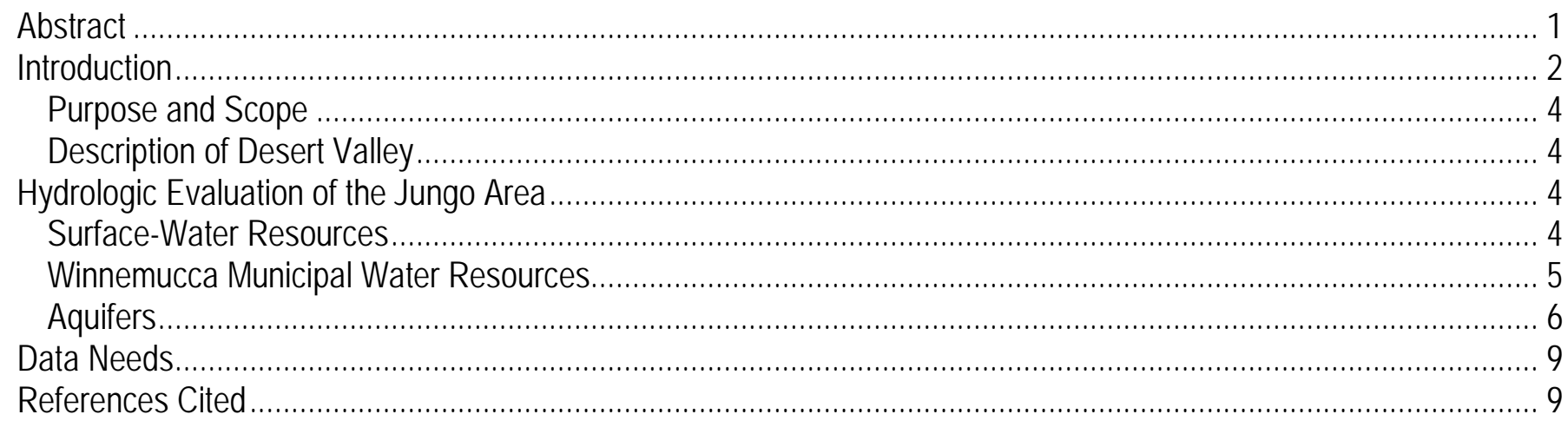

\section{Figures}

Figure 1. Proposed Jungo landfill site (top) and railroad near Jungo in southern Desert Valley, Nevada................... 2

Figure 2. Selected locations and hydrologic features in and around Desert Valley, Nevada .................................. 3

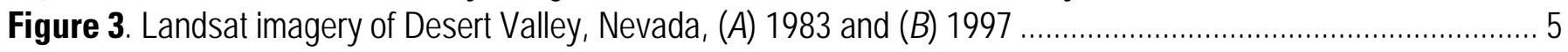

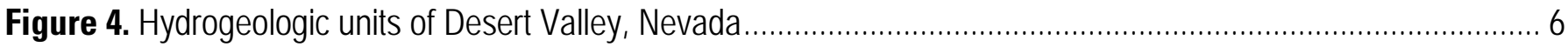

Figure 5. Groundwater-level contours and flow directions in Desert Valley, Nevada ........................................... 8 


\section{Conversion Factors and Datums}

\section{Conversion Factors}

Inch/Pound to SI

\begin{tabular}{lcl}
\hline & \multicolumn{1}{c}{ Multiply } & \multicolumn{1}{c}{ To obtain } \\
\hline inch (in.) & Length & \\
inch (in.) & 2.54 & centimeter (cm) \\
foot (ft) & 25.4 & millimeter (mm) \\
mile (mi) & 0.3048 & meter (m) \\
\hline & 1.609 & kilometer $(\mathrm{km})$ \\
\hline square mile $\left(\mathrm{mi}^{2}\right)$ & Area & \\
square mile $\left(\mathrm{mi}^{2}\right)$ & 259.0 & hectare (ha) \\
\hline & 2.590 & square kilometer $\left(\mathrm{km}{ }^{2}\right)$ \\
\hline foot per day (ft/d) & Hydraulic conductivity & \\
\hline & 0.3048 & meter per day (m/d) \\
\hline foot per mile (ft/mi) & Hydraulic gradient & \\
\hline
\end{tabular}

\section{Datums}

Vertical coordinate information is referenced to the North American Vertical Datum of 1988 (NAVD 88). Horizontal coordinate information is referenced to the North American Datum of 1983 (NAD 83). Altitude, as used in this report, refers to distance above the vertical datum. 


\title{
Hydrologic Evaluation of the Jungo Area, Southern Desert Valley, Nevada
}

\author{
By Thomas J. Lopes
}

\begin{abstract}
Recology $^{\mathrm{TM}}$, the primary San Francisco waste-disposal entity, is proposing to develop a Class 1 landfill near Jungo, Nevada. The proposal calls for the landfill to receive by rail about 20,000 tons of waste per week for up to 50 years. On September 22, 2009, the Interior Appropriation (S.A. 2494) was amended to require the U.S. Geological Survey to evaluate the proposed Jungo landfill site for: (1) potential water-quality impacts on nearby surface-water resources, including Rye Patch Reservoir and the Humboldt River; (2) potential impacts on municipal water resources of Winnemucca, Nevada; (3) locations and altitudes of aquifers; (4) how long it will take waste seepage from the site to contaminate local aquifers; and (5) the direction and distance that contaminated groundwater would travel at 95 and 190 years. This evaluation was based on review of existing data and information.

Desert Valley is tributary to the Black Rock Desert via the Quinn River in northern Desert Valley. The Humboldt River and Rye Patch Reservoir would not be affected by surface releases from the proposed Jungo landfill site because they are in the Humboldt basin. Winnemucca, on the Humboldt River, is 30 miles east of the Jungo landfill site and in the Humboldt basin. Groundwater-flow directions indicate that subsurface flow near the proposed Jungo landfill site is toward the south-southwest. Therefore, municipal water resources of Winnemucca would not be affected by surface or subsurface releases from the proposed Jungo landfill site.

Basin-fill aquifers underlie the 680-square-mile valley floor in Desert Valley. Altitudes around the proposed Jungo landfill site range from 4,162 to 4,175 feet. Depth to groundwater is fairly shallow in southern Desert Valley and is about 60 feet below land surface at the proposed Jungo landfill site. A groundwater divide exists about 7 miles north of the proposed Jungo landfill site. Groundwater north of the divide flows north towards the Quinn River. South of the divide and near the proposed Jungo landfill site, groundwater flows in a south-southwesterly direction. Data are insufficient to determine whether groundwater eventually flows into Rye Patch Reservoir or other adjacent valleys. Estimates indicate that contaminants would travel about 0.02 mile and a maximum of 2.5 miles in 95 years and about 0.04 mile and a maximum of 5.0 miles in 190 years. The closest supply wells that could be impacted by contaminants are 5 to 6 miles downgradient and are used for industry, irrigation, and stock watering.
\end{abstract}




\section{Introduction}

Recology $^{\mathrm{TM}}$, the primary San Francisco waste disposal entity, is proposing to develop a Class 1 landfill near Jungo, Nevada (figs. 1 and 2). The proposal calls for the landfill to receive by rail about 20,000 tons of waste per week for up to 50 years. The Interior Appropriation (S.A. 2494) was amended on September 22, 2009, to require the U.S. Geological Survey (USGS) to evaluate the water-quality impact of the proposed Jungo landfill site.

The proposed Jungo landfill site is located in southern Desert Valley, about 30 mi west of Winnemucca, Humboldt County, Nevada. Recology ${ }^{\mathrm{TM}}$ received a conditional use permit from Humboldt County Regional Planning in 2007 for the site, but the Nevada Department of Environmental Protection permit is still in process. The scale of the proposed operation, potentially one of the largest landfills in the Nation, as well as the out-of-state source, has created significant media attention. The amendment requires the USGS to evaluate potential contamination of water resources from material in a Class 1 landfill (construction materials, non-liquid waste including dried sludge, shredded tires, and asbestos). The evaluation is to determine (1) potential impacts on nearby surface-water resources, including Rye Patch Reservoir and the Humboldt River; (2) potential impacts on municipal water resources of Winnemucca, Nevada; (3) the locations and altitudes of aquifers; (4) the time it will take waste seepage from the site to contaminate local aquifers; and (5) the direction and distance contaminated groundwater would travel at 95 and 190 years.

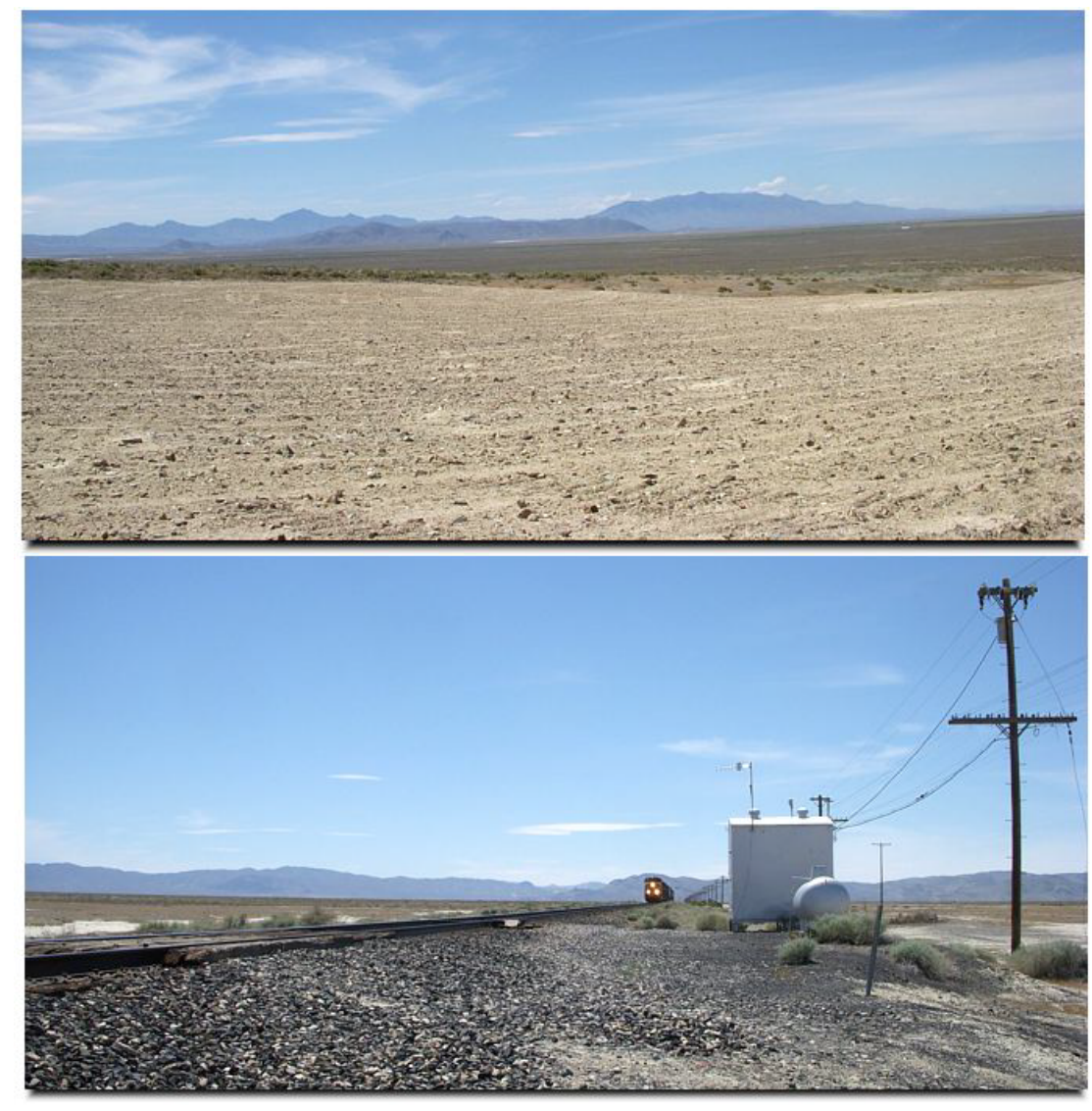

Figure 1. Proposed Jungo landfill site (top) and railroad near Jungo in southern Desert Valley, Nevada. Photographs courtesy of the Nevada Division of Environmental Protection. 


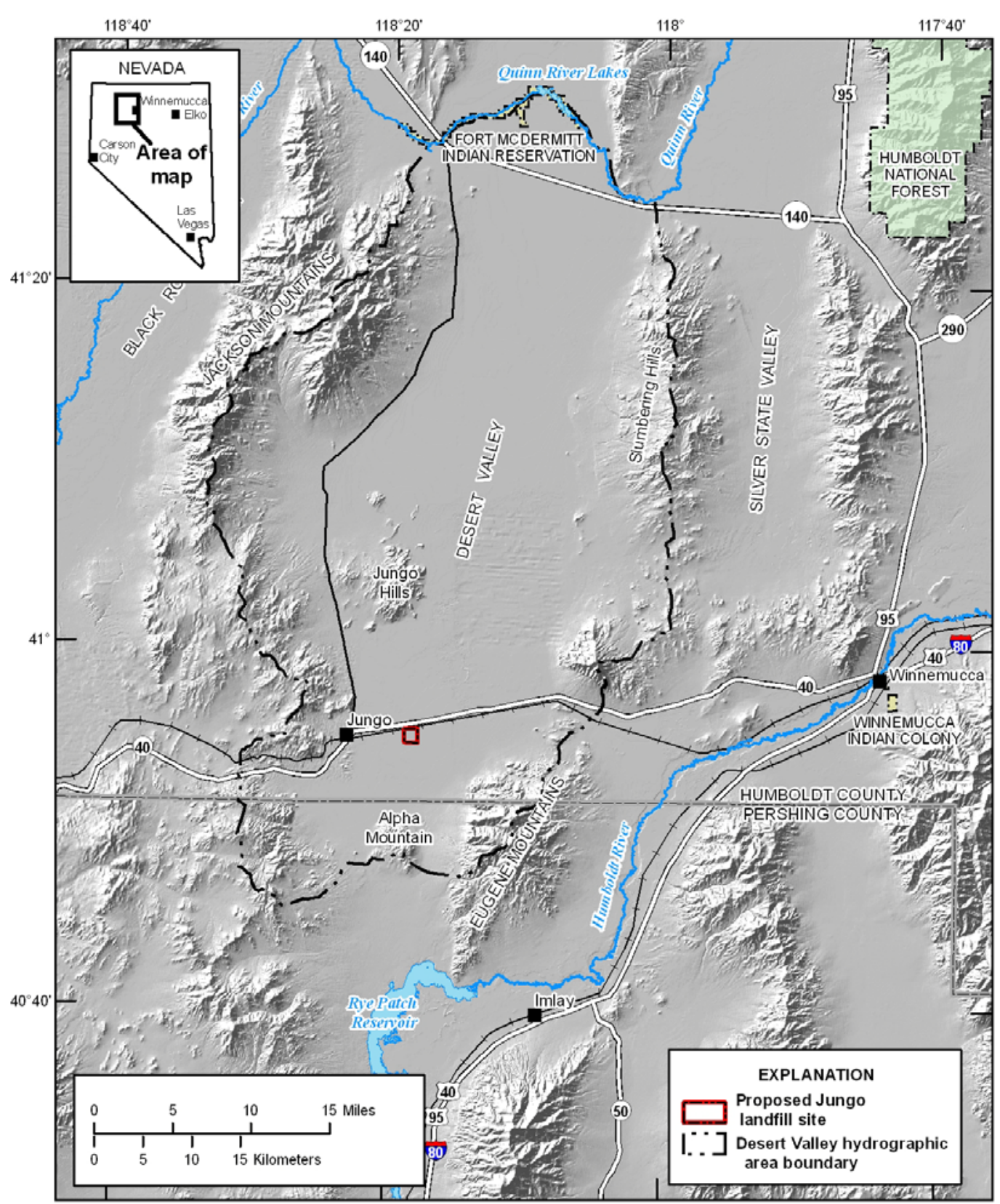

Base from U.S. Geological Survey digital data, 1:100,000-scale, 2008

Universal Transverse Mercator projection, Zone 11

World Geodetic System 1984

Shaded-relief base from 30-meter NED digital data, 2000;

sun-illumination from northwest at 45 degrees above horizon

Figure 2. Selected locations and hydrologic features in and around Desert Valley, Nevada. 


\section{Purpose and Scope}

This report presents an evaluation of potential impacts of the proposed Jungo landfill site on the quality of water resources in the area. The evaluation is based on a review of existing data and reports, which were used to estimate groundwater velocities and direction.

\section{Description of Desert Valley}

The USGS has conducted several previous groundwater investigations of Desert Valley (Sinclair, 1962; Berger, 1992, 1995). The most recent report (Berger, 1995) included a groundwater flow model appropriate for the early 1990s. Desert Valley is a north-trending structural basin. The valley floor is about $55 \mathrm{mi}$ long and $12 \mathrm{mi}$ wide with a topographic relief of less than $100 \mathrm{ft}$. Jungo is an abandoned settlement at the southern end of the valley. Jungo was a railroad siding for iron ore mined in the Jackson Mountains and had a post office from 1911 to 1952 (Carlson, 1974, p. 147). The valley floor in the Jungo area is at an altitude of about 4,170 ft. Topographic relief in a 3-mi radius of the proposed Jungo landfill site does not exceed $50 \mathrm{ft}$. The valley floor is mostly alkali lake sediments and sand dunes. A large area west of the proposed Jungo landfill site is covered by a hard-pan alkali flat.

The climate of Desert Valley ranges from subhumid in high altitudes of the Jackson Mountains to arid on the valley floor. Precipitation is controlled primarily by the rain-shadow effect of the Sierra Nevada 150 mi to the west. The Jackson Mountains, which border the western side of Desert Valley and cause a similar orographic effect, receive most of the precipitation that falls in the area. Precipitation is generally greater on west-facing slopes than east-facing slopes and increases with altitude (Huxel and others, 1966, p. 15); however, variations can be caused by local topography throughout the area. Thunderstorms are the primary source of precipitation in the summer months. Snow and occasional freezing rain fall in the winter months. Mean annual precipitation at the Jungo Meyer Ranch weather station (operated from 1968 through 1986) was 8.7 in. Mean annual precipitation for 1971-2000 was 8.3 in. at Winnemucca (altitude of 4,300 ft) and Imlay, Nev. (altitude of 4,260 ft), the closest currently operating weather stations to southern Desert Valley

(http://www.wrcc.dri.edu/summary/Climsmnv.html).

\section{Hydrologic Evaluation of the Jungo Area}

\section{Surface-Water Resources}

Desert Valley is tributary to the Black Rock Desert via the Quinn River in northern Desert Valley (Berger, 1995). The Humboldt River and Rye Patch Reservoir would not be affected by surface releases from the proposed Jungo landfill site because they are in the Humboldt basin. The proposed Jungo landfill site is in a shallow depression in southern Desert Valley. Local runoff accumulates in the alkali flat about 2 mi west of the site. Floods during 1983 and 1997 affected much of western Nevada. However, Landsat imagery taken during these years indicated that there was no water in the alkali flat (fig. 3). Much larger events would have to occur for runoff from the landfill site to reach the alkali flat. The flat would then have to overflow into northern Desert Valley to affect surface-water resources. 


\section{Winnemucca Municipal Water Resources}

Winnemucca had a population of 7,659 in 2008

(http://www.nsbdc.org/what/data_statistics/demographer/pubs/pop_increase). Winnemucca is $30 \mathrm{mi}$ east of the proposed Jungo landfill site and in the Humboldt basin. Groundwater-flow directions, discussed below, indicate that subsurface flow near the site is towards the south-southwest. Wind-blown contaminants could reach the Winnemucca area, but dispersion likely would dilute concentrations to an undetectable level in surface or subsurface water resources. Therefore, municipal water resources of Winnemucca would not be affected by surface or subsurface releases from the proposed Jungo landfill site.

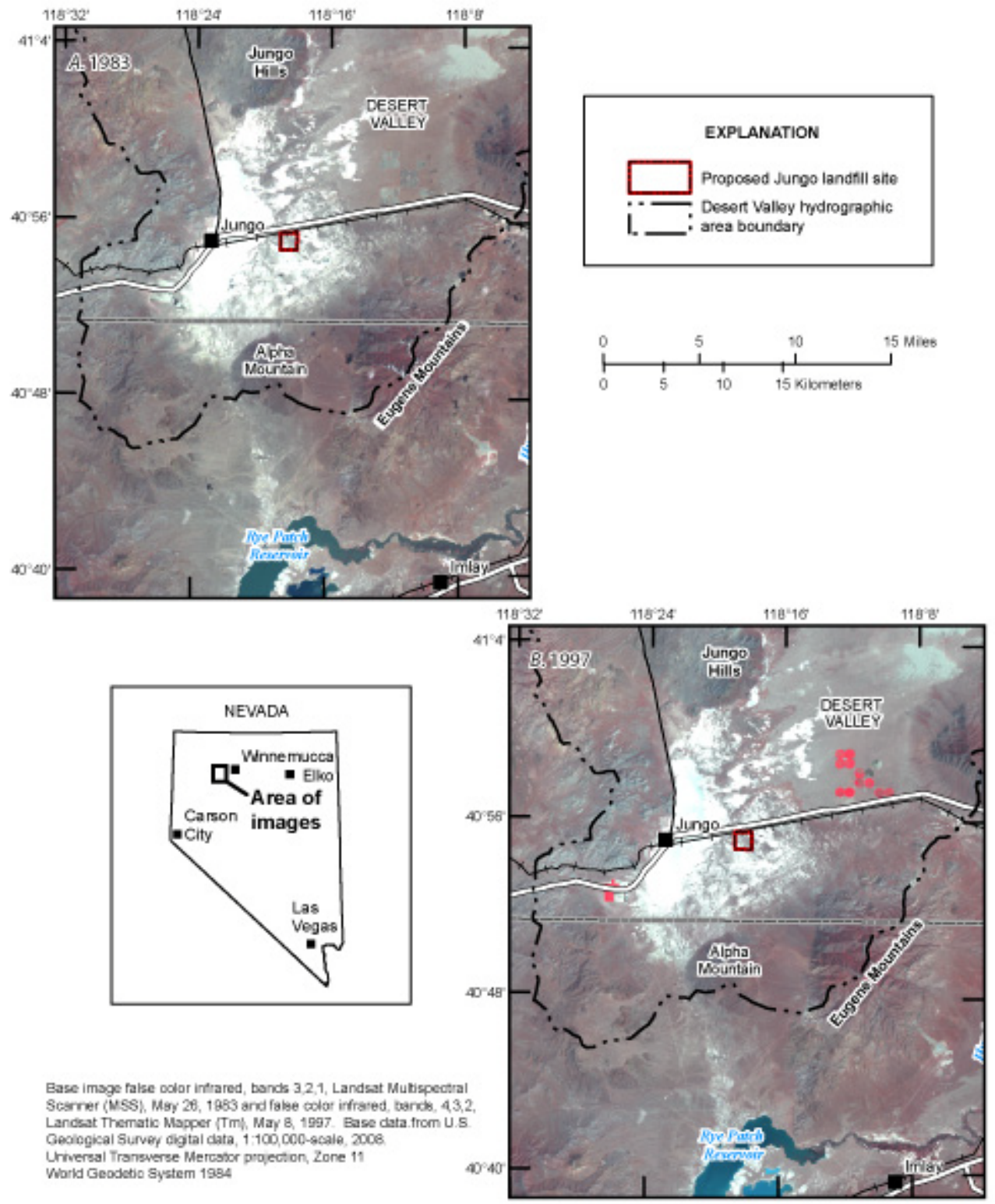

Figure 3. Landsat imagery of Desert Valley, Nevada, $(A) 1983$ and (B) 1997. 


\section{Aquifers}

Aquifers in the study area can be subdivided into two lithologic types primarily based on their ability to transmit and store water (fig. 4; Berger, 1995). Consolidated-rock aquifers make up the surrounding mountains, underlie basin-fill aquifers, and transmit and store little water. Basin-fill aquifers are unconsolidated to semi-consolidated sediments and consist of sand dunes, older and younger alluvium, hard-pan, and lake deposits. Basin-fill aquifers store and transmit large quantities of water compared to consolidated-rock aquifers. Supply wells in Desert Valley pump water from basin-fill aquifers.

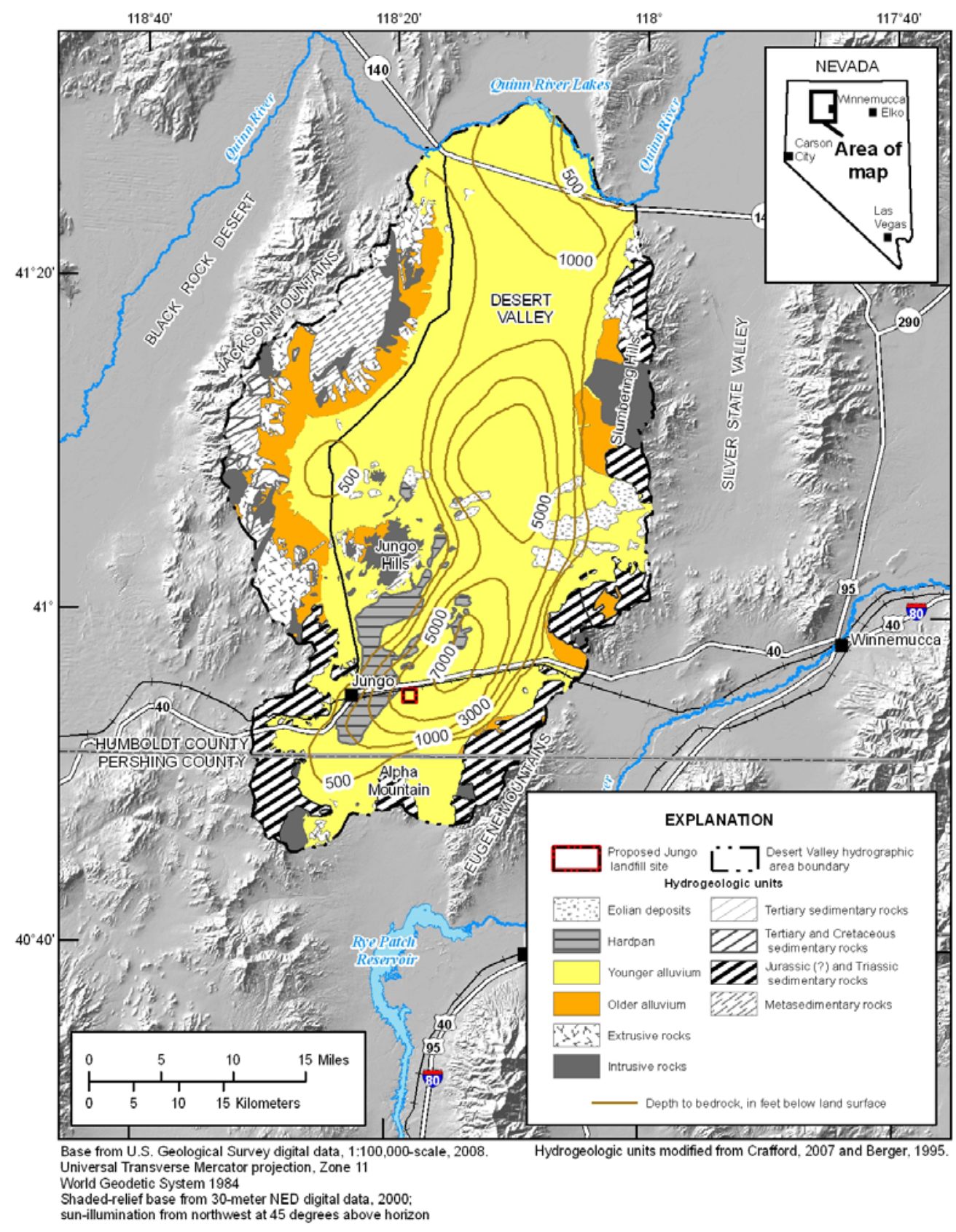

Figure 4. Hydrogeologic units of Desert Valley, Nevada. 
The proposed Jungo landfill site is on basin-fill sediments. Four borings (Nevada well log Nos. 103120-103123) at the boundary of the site encountered mostly silty sand, sandy silt, and silty clay to a depth of $100 \mathrm{ft}$. Similar fine-grained sediments were encountered in other borings in the area. Coarse-grained sediments tend to occur closer to the surrounding hills and at greater depths. Hydraulic conductivities and groundwater velocities are low in fine-grained sediments compared to coarse-grained sediments. Clay particles also have large surface areas that adsorb contaminants, which further lowers contaminant velocities in groundwater.

Basin-fill aquifers underlie the valley floor, which has a total area of $680 \mathrm{mi}^{2}$. Altitudes around the Proposed Jungo landfill site range from 4,162 to 4,175 ft. Depth to groundwater is fairly shallow in southern Desert Valley and is about $60 \mathrm{ft}$ below land surface at the proposed Jungo landfill site. Depth to groundwater generally ranges between 40 and $100 \mathrm{ft}$ below land surface in other wells in the basinfill aquifer. Contaminants from the landfill could reach the basin-fill aquifer; however, the site will be constructed with liners to mitigate subsurface contamination.

Recharge through sand dunes has created a groundwater divide about $7 \mathrm{mi}$ north of the proposed Jungo landfill site (fig. 5; Berger, 1992, 1995). Groundwater north of the divide flows north towards the Quinn River. Groundwater flows in a south-southwesterly direction south of the divide and near the proposed Jungo landfill site. Data are insufficient to determine whether groundwater eventually flows into Rye Patch Reservoir or other adjacent valleys.

A combination of Darcy's Law, which describes groundwater flow through aquifers, and the velocity equation of hydraulics were used to estimate how far contaminants could travel from the site:

$$
q=\left(K^{*} I\right) / n
$$

where,

$q$ is the average linear groundwater velocity, in $\mathrm{ft} / \mathrm{d}$;

$K$ is the horizontal hydraulic conductivity of the aquifer, in $\mathrm{ft} / \mathrm{d}$;

$I$ is the unitless hydraulic gradient; and

$n$ is the unitless effective porosity of the aquifer.

Slug tests done on four monitoring wells at the proposed Jungo landfill site had $K$ values that ranged from 0.26 to $0.45 \mathrm{ft} / \mathrm{d}$ and averaged $0.34 \mathrm{ft} / \mathrm{d}$ (Golder Associates, Inc., 2008, appendix D). Near the proposed Jungo landfill site, the maximum hydraulic conductivity is $50 \mathrm{ft} / \mathrm{d}$ (Berger, 1995) and the maximum hydraulic gradient is about $4 \mathrm{ft} / \mathrm{mi}$. The porosity of basin-fill sediments ranges from about 0.1 to 0.2 (Cohen, 1963). Using these values in equation 1, estimates indicate that contaminants would travel about $0.02 \mathrm{mi}$ and a maximum of $2.5 \mathrm{mi}$ in 95 years. In 190 years, contaminants would travel about $0.04 \mathrm{mi}$ and a maximum of $5.0 \mathrm{mi}$. This assumes that flow through unsaturated sediments overlying the aquifer is instantaneous and that contaminants travel the same rate as water. However, reaction with unsaturated and saturated sediments slows contaminant transport so these values represent maximum distances contaminants could travel under the existing hydraulic gradient. The closest supply wells that could be impacted by contaminants are 5 to $6 \mathrm{mi}$ downgradient in the southern Desert Valley and are used for industry, irrigation, and stock watering. 


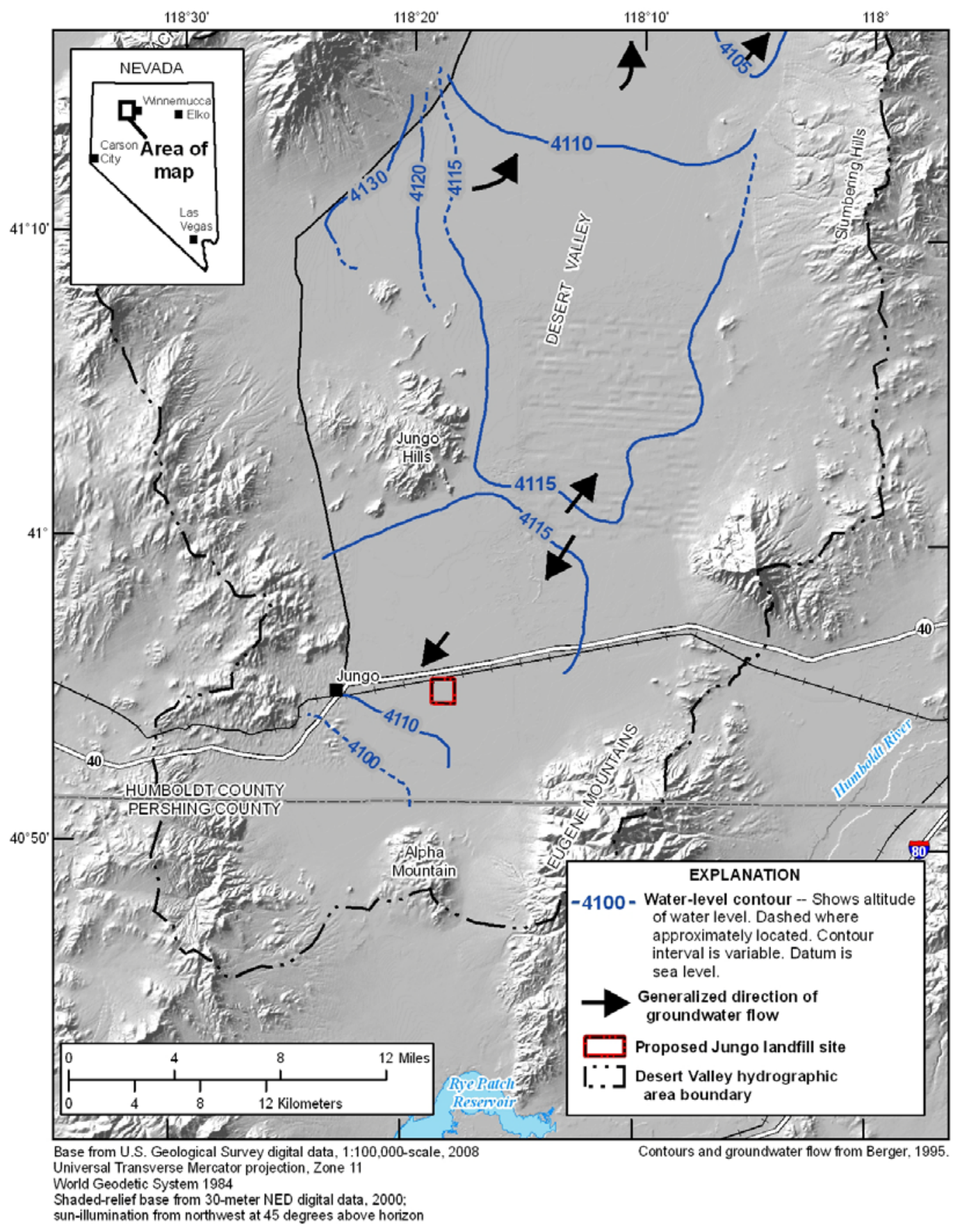

Figure 5. Groundwater-level contours and flow directions in Desert Valley, Nevada. 


\section{Data Needs}

Estimates indicate that a subsurface release of contaminants from the proposed Jungo landfill site would not reach supply wells for more than 200 years. However, determining which wells could potentially be affected is complex because the flat topography makes it difficult to accurately measure groundwater altitudes and estimate gradients and flow directions in southern Desert Valley. Some basic groundwater-quality data (such as sodium and chloride) exists in the Jungo area, but anthropogenic contaminants (such as volatile organic compounds) are known to occur along railroads. It would be prudent to assess groundwater for anthropogenic contaminants prior to construction of the facility and to age-date the groundwater to verify groundwater velocities. It also is unknown if groundwater is moving south to Rye Patch Reservoir or west to the Black Rock Desert. This work could be done by Recology ${ }^{\mathrm{TM}}$ or by an impartial third party. Data needed to better evaluate the Jungo area include:

1. Survey wells using a differential global positioning system to measure well and groundwater altitudes to within $0.1 \mathrm{ft}$;

2. Sample groundwater around the proposed Jungo landfill site to characterize baseline water quality;

3. Use geochemical techniques to date groundwater and verify groundwater velocities; and

4. Drill wells to the south and west to determine directions of groundwater flow from southern Desert Valley.

\section{References Cited}

Berger, D.L., 1992, Ground-water recharge through active sand dunes in northwestern Nevada: Water Resources Bulletin, v. 28, no. 5, p. 959-965.

Berger, D.L., 1995, Ground-water conditions and effects of mine dewatering in Desert Valley, Humboldt and Pershing Counties, northwestern Nevada, 1962-91: U.S. Geological Survey WaterResources Investigations Report 95-4119, 94 p.

Carlson, H.S., 1974, Nevada place names-A geographical dictionary: Reno, University of Nevada Press, $282 \mathrm{p}$.

Cohen, Philip, 1963, Specific-yield and particle-size relations of Quaternary alluvium, Humboldt River Valley, Nevada: U.S. Geological Survey Water-Supply Paper 1669-M, 24 p.

Crafford, A.E.J., 2007, Geologic Map of Nevada: U.S. Geological Survey Data Series 249, 1 CD-ROM, 46 p., 1 plate

Golder Associates, Inc., 2008, Application for a permit to construct and operate a Class I landfill facility, Jungo Disposal Site, Humboldt County: Golder Associates, Inc., Roseville, California.

Huxel, C.J., Jr., Parkes, J.E., and Everett, D.E., 1966, Effects of irrigation development on the water supply of Quinn River Valley area, Nevada and Oregon, 1950-64: Nevada Department of Conservation and Natural Resources, Water Resources Bulletin 34, 80 p.

Sinclair, W.C., 1962, Ground-water resources of Desert Valley, Humboldt and Pershing Counties, Nevada: Nevada Division of Water Resources, Ground-Water Resources Reconnaissance Report 7, $23 \mathrm{p}$. 
This page left intentionally blank 
Publishing support provided by the U.S. Geological Survey Publishing Network, Tacoma Publishing Service Center

For more information concerning the research in this report, contact the Director, Nevada Water Science Center

U.S. Geological Survey

2730 N. Deer Run Road

Carson City, NV 89701

http://nevada.usgs.gov/water 


$$
\text { 弮 }
$$

